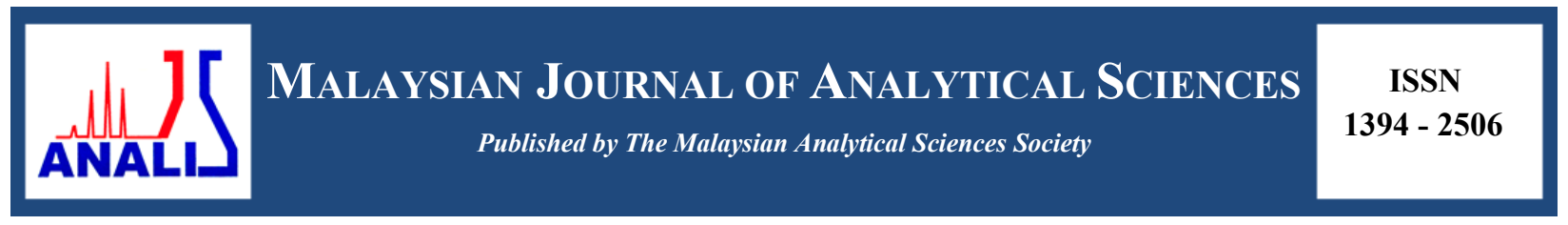

\title{
TOTAL PHENOLIC, FLAVONOID CONTENT AND ANTIOXIDANT ACTIVITY OF Clinacanthus nutans LEAVES BY WATER-BASED ULTRASONIC ASSISTED EXTRACTION
}

\author{
(Kandungan Fenolik, Flavonoid dan Aktiviti Antioksidan bagi Clinacanthus nutans \\ Menggunakan Bantuan Pengekstrakan Ultrasonik Berasaskan Air)
}

\author{
Nurul Amila Fadhlin Baharuddin ${ }^{1}$, Mariam Firdhaus Mad Nordin ${ }^{1 *}$, Noor Azian Morad ${ }^{1}$, Nor Ilia Anisa Aris ${ }^{1}$, \\ Mohd Azizi Che Yunus ${ }^{2}$ \\ ${ }^{I}$ Shizen Conversion and Separation Technology (SHIZEN Ikohza), \\ Malaysia-Japan International Institute of Technology (MJJIT) \\ Universiti Teknologi Malaysia, Jalan Sultan Yahya Petra, 54100 Kuala Lumpur \\ ${ }^{2}$ Centre of Lipid Engineering and Applied Research (CLEAR) \\ Universiti Teknologi Malaysia, 81310 Johor Bharu, Johor, Malaysia \\ *Corresponding author: mariamfirdhaus@utm.my
}

Received: 16 April 2017; Accepted: 7 March 2018

\begin{abstract}
Clinacanthus nutans (C. nutans) is a prominent herb species that widely cultivated in Southeast Asia region. The effect of waterbased ultrasonic assisted extraction at various temperature $\left(30\right.$ to $\left.60{ }^{\circ} \mathrm{C}\right)$ and time $(5$ to 30 minutes) on the total phenolic, flavonoid content and antioxidant activity in $C$. nutans leaves extract was investigated. Acquired extract was quantified for its total phenolic, flavonoid content and antioxidant activity by Folin-Ciocalteu, aluminium chloride test and 2, 2-diphenyl-1picrylhydrazyl (DPPH) assay, respectively. The result has revealed that the highest temperature led to the degradation of bioactive compound in $C$. nutans leaves. The highest phenolic content and antioxidant activity achieved at $55^{\circ} \mathrm{C}$ and 25 minutes with $13.87 \pm 0.15 \mathrm{mg}$ gallic acid $\mathrm{g}^{-1}$ dry sample and $52.88 \pm 3.91 \%$ inhibition, respectively. Meanwhile, greatest flavonoid content was obtained for $12.25 \pm 1.01 \mathrm{mg}$ quercetin $\mathrm{g}^{-1}$ of dry sample at $55^{\circ} \mathrm{C}$ and 15 minutes of extraction. From this study, it was shown that $C$. nutans extraction has gained benefit from ultrasonic assisted extraction and has possibilities of being used for the herbs utilisation of beneficial food materials, nutraceuticals and pharmaceuticals at manufacturing industry.
\end{abstract}

Keywords: Clinacanthus nutans, ultrasonic assisted extraction, phenolic, flavonoid, antioxidant

\section{Abstrak}

Clinacanthus nutans (C. nutans) adalah spesies herba terkemuka yang ditanam secara meluas di rantau Asia Tenggara. Dalam kajian ini, kesan ultrasonik pada suhu $\left(30\right.$ hingga $\left.60^{\circ} \mathrm{C}\right)$ dan masa (5 hingga 30 minit) yang berbeza terhadap kandungan fenolik, flavonoid dan aktiviti antioksida di dalam ekstrak daun $C$. nutans telah dikaji. Hasil pengekstrakan yang diperolehi telah dianalisa jumlah kandungan fenolik, flavonoid serta aktiviti antioksida setiapnya dengan menggunakan kaedah Folin-Ciocalteu, aluminium klorida dan ujian 2, 2-difenil-1-pikrilhidrazil (DPPH). Keputusan menunjukan bahawa, suhu yang tinggi menyebabkan penguraian sebatian bioaktif di dalam ekstrak $C$. nutans. Jumlah kandungan fenolik dan aktiviti antioksida yang tertinggi masing-masing telah didapati pada keadaan $55^{\circ} \mathrm{C}$ dan 25 minit dengan nilai masing-masing adalah sebanyak $13.87 \pm$ $0.15 \mathrm{mg}$ asid galik g ${ }^{-1}$ sampel kering dan $52.88 \pm 3.91 \%$ perencatan. Sementara itu, kandungan flavonoid pula telah diperolehi sebanyak $12.25 \pm 1.01 \mathrm{mg}$ quercetin $\mathrm{g}^{-1}$ sampel kering pada keadaan pengekstrakan $55{ }^{\circ} \mathrm{C}$ dan 15 minit. Hasil kajian ini menunjukan bahawa, kaedah pengekstrakan dengan bantuan ultrasonik amat berguna dalam pengekstrakan daun $C$. nutans dan mempunyai peluang yang tinggi dalam penggunaan herba yang bermanfaat di dalam industri pembuatan makanan, nutraseutikal serta farmaseutikal. 


\section{Nurul Amila et al: TOTAL PHENOLIC, FLAVONOID CONTENT AND ANTIOXIDANT ACTIVITY OF Clinacanthus nutans LEAVES BY WATER-BASED ULTRASONIC ASSISTED EXTRACTION}

Kata kunci: Clinacanthus nutans, pengekstrakan bantuan ultrasonik, fenolik, flavonoid, antioksidan

\section{Introduction}

In recent times, there has been increasing consumer interest towards medicinal plants since it is healthier and free from side effects caused by synthetic products or drugs. Majority of the world population still rely upon plants and their extracts for primary health care and needs. The use of medicinal plants as herbal remedies still maintained their therapeutic effect in spite of overwhelming influence of modern medicine and tremendous advances made in the production of synthetic drugs. Their effectiveness, economical and less toxicity has made it popular and approved as a mode of treating diseases even in these modern times [1].

The pharmacological properties and phytoconstituents information in some herbal medicinal plants have offered a great potential to be used in medicinal research. Clinacanthus nutans is one of the herbs plant that belongs to the family of Acanthaceae and locally known as elephant's trunk leaves or Sabah snake grass in Malaysia. This plant has been widely cultivated throughout tropical regions including South East Asia and China [2]. Clinacanthus nutans leaves has been traditionally used to treat various diseases including skin rashes, insect and snake bites, lesions caused by herpes simplex virus, diabetes, and gout in Malaysia, Indonesia, Thailand and China [3]. In Malaysia, it is commonly used for its nourishing and antioxidant properties [4]. Antioxidant activity is very important in life as it helps to neutralise the oxidative damage caused by the production of free radicals in the body [5].

Natural antioxidant has more benefits, such as nontoxic and more easily decomposed by bodies than artificial antioxidant. Clinacanthus nutans leaves extract is rich in natural antioxidant due to the phytochemical compounds presence in the plants that provide the antioxidant properties including phenolic and flavonoid compounds [6]. Phenolic and flavonoid compounds have been known for their ability to scavenge free radical reaction redox reaction due to their properties that can act as reducing agents, hydrogen donors, singlet oxygen quenchers and also other biological effect that provide health benefits for human beings [7]. Many research have been done in quantification of the total phenolic, flavonoid content and antioxidant activity from $C$. nutans leaves using organic solvents in conventional and modern extraction methods [8]. Conventional extraction method includes maceration and Soxhlet extraction is typically carried out at a longer extraction temperature and time which can cause degradation of thermal-labile compound including phenolic compounds. This extraction method is also known for its low efficiency and potentially hazardous to the environment due to high amount of solvent used which is very toxic, carcinogenic and not easily decomposed $[8,9]$.

Recently, diverse extraction technology has been developed in providing a new and simpler sample preparation methods with high performance such as supercritical fluid extraction (SCFE), accelerated solvent extraction (ASE), subcritical water extraction (SWE) and ultrasound assisted extraction (UAE) [10]. Ultrasonic-assisted extraction (UAE) is an effective alternative for conventional extraction method that offers an inexpensive and environmental friendly extraction process. This process is based on the use of mechanical waves at a frequency above the threshold of human hearing $(>16 \mathrm{kHz})$. The enhancement of solvent penetration into plants cells attributed by the mechanical effects that travel through the solvent media and production of acoustic cavitation bubbles which disrupts the plant cell wall resulting the release of desired bioactive compound into the solvent matrix [11]. UAE provides a high production yield, lower energy input and temperature used, shorter extraction time, low solvent consume and improve extraction of thermal-labile compound at low temperature $[12,13]$. Previous studies have reported the extraction on the bioactive compounds of $C$. nutans by other extraction techniques, however, no information is available on the effect of ultrasound-assisted extraction using water as the solvent medium on phenolics content and antioxidant in $C$. nutans leaves. Therefore, the goal of present investigation was to study the effect of temperature and time in water based ultrasonic assisted extraction on total phenolic, flavonoid content and antioxidant activity from C. nutans leaves. 


\section{Sample preparation}

\section{Materials and Methods}

The sources of fresh leaves of $C$. nutans were collected from a local supplier, Kiza Herbs farm which is located in Temerloh, Pahang. Initially, the C. nutans leaves was first separated from the stems and washed thoroughly to remove impurities. Then, the leaves were dried at $40{ }^{\circ} \mathrm{C}$ for overnight. The dried leaves was further grinded and sieved through $1.18 \mathrm{~mm}$ mesh size. The powdered leaves were kept stored in air-tight vacuum pack at room temperature prior to the extraction process.

\section{Ultrasonic assisted extraction}

Five grams of powdered sample in $85 \mathrm{ml}$ of distilled water was ultrasonicated at different temperatures of $30,35,45$, 55 and $60{ }^{\circ} \mathrm{C}$ and times for 5, 15, 25 and 30 minutes using a $28 \mathrm{kHz}$ ultrasonic water bath (CT-420B Digital Ultrasonic Cleaner). The residual was separated and centrifuged at $1500 \mathrm{rpm}$ for 15 minutes. The extracts were filtered and used for further analysis. All extractions were done in triplicates.

\section{Analysis of phenolic content}

The phenolics was analysed using Folin-Ciocalteu method according to Susanti et al. [9] with some modification. About $0.5 \mathrm{~mL}$ of leaves extract $(10 \%)$ was added into test tube containing $2.5 \mathrm{~mL}$ Folin-Ciocalteu reagent and the mixture was left to stand for 5 minutes before adding $2 \mathrm{~mL}$ of sodium carbonate solution $(75 \mathrm{~g} / \mathrm{L})$ and vortexed (Heidolph, Germany) for $30 \mathrm{~s}$. Afterwards, the mixture was incubated for two hours at room temperature to allow the reaction to take place. The resulting blue complex indicated the presence of TPC which was measured spectrophotometrically using a UV-VIS spectrophotometer (SP-3000nano, Japan) at $765 \mathrm{~nm}$ of absorbance. Phenolic amount was quantified based on $\mathrm{mg}$ gallic acid equivalent (GAE) per gram of dry sample. All determination conducted in triplicates.

\section{Analysis of flavonoid content}

Total flavonoids were analysed using aluminium chloride method modified from Tan et al. [14]. Briefly, $0.5 \mathrm{~mL}$ of extracted aliquot leaves (10\%) was mixed with $2 \mathrm{~mL}$ of distilled water and $0.15 \mathrm{~mL}$ of sodium nitrite (5\%). Then, about $0.15 \mathrm{~mL}$ of aluminium chloride solution $(10 \%)$ was added after incubated for $5 \mathrm{~min}$. The mixture was mixed thoroughly and left again for $6 \mathrm{~min}$. Subsequently, $2 \mathrm{~mL}$ of sodium hydroxide $(4 \%)$ was added and topped up the volume of mixture to $5 \mathrm{~mL}$ with distilled water. Finally, the mixture was shaken vigorously using a vortex (Fisherbrand, Denmark) and left in a dark for 15 minutes. Flavonoid content was measured at absorbance of $510 \mathrm{~nm}$ using a UV-VIS spectrophotometer (SP-3000nano, Japan) and the result was demonstrated in term of mg quercetin equivalent $(\mathrm{QE})$ per gram of dry sample. All determination performs in triplicates.

\section{Analysis of antioxidant activity}

The method for estimating antioxidant activity of the extracts was adapted from Sharifi et al. [15] with some changes. Concisely, $3.5 \mathrm{~mL}$ of $(0.004 \%)$ ethanolic 2,2'-diphenyl-1-picrylhydrazyl (DPPH) was mixed with $0.5 \mathrm{~mL}$ ethanolic leaves extract (25\%). Next, the mixture was allowed to stand for 30 minutes at room temperature before spectrophotometrically measured using a UV-VIS spectrophotometer (SP-3000nano, Japan) at $517 \mathrm{~nm}$ of absorbance. The antioxidant activity was evaluated by comparing the sample absorbance with the control. Each measurement was done in triplicate. The calculation of antioxidant activity was made based on following equation:

$$
\text { Antioxidant Activity }(\% \text { inhibition })=\frac{A_{c}-A_{S}}{A_{C}} \times 100
$$

where $A c$ is absorbance of control and $A s$ is absorbance of tested sample.

\section{Statistical analysis}

The data was computed and statistically analysed using the Microsoft Excel 2013 software. All experiments were performed in triplicates and results were expressed as mean \pm standard deviation (S.D). Two-way analysis of variance (ANOVA) was established using Minitab Software 17 for estimating the outcome of time and temperature instantaneously. All parameters were measured to provide statistically significant different to the process and the significant value was considered as $p<0.05$ regarding to $95 \%$ confidence level. Meanwhile, the higher $f$ value would responded as high significant effect to the process. 


\section{Nurul Amila et al: TOTAL PHENOLIC, FLAVONOID CONTENT AND ANTIOXIDANT ACTIVITY OF Clinacanthus nutans LEAVES BY WATER-BASED ULTRASONIC ASSISTED EXTRACTION}

\section{Analysis of total phenolic content}

\section{Results and Discussion}

Ultrasound-assisted extraction (UAE) is one promising alternative to traditional methods as it is easy, inexpensive and very environmental friendly. The major advantages of the process are noted when it produces higher yield and fast rate extraction process. Temperature and time are the two important parameters for the extraction process in optimising the bioactive compounds including phenolics and flavonoids from plant sample. In this study, the effect of different temperatures $\left(30\right.$ to $60{ }^{\circ} \mathrm{C}$ ) and time (5 to 30 minutes) in UAE on total phenolic content (TPC), total flavonoid content (TFC) and antioxidant activity of $C$. nutans were investigated and discussed.

Figure 1 shows an increasing trend of TPC of $C$. nutans leaves extracts within the range of $11.05 \pm 0.71$ to $13.87 \pm$ $0.15 \mathrm{mg} \mathrm{GAE} / \mathrm{g}$ dry sample as the increase in temperature from 30 to $55^{\circ} \mathrm{C}$. The highest TPC $(13.87 \pm 0.15 \mathrm{mg}$ $\mathrm{GAE} / \mathrm{g}$ dry sample) was achieved at $55^{\circ} \mathrm{C}$ and 25 minutes of extraction. However, a further increase in temperature from 55 to $60^{\circ} \mathrm{C}$ has resulted in decreasing of TPC. This finding was in agreement with Altemimi et al. [16] which indicated that the increase of ultrasonic temperature from 30 to $50{ }^{\circ} \mathrm{C}$ has increased the extraction of TPC in peach extracts and showed a reduction afterwards. The increase of TPC may be due to the increase of both solubility of solute and solvent diffusivity as the increase of temperature enhanced the efficiency of TPC extraction. Besides, the increase of extraction temperature with the aid of mechanical waves from sonication has increased the production of acoustic cavitation bubble that destroyed the plant cell wall resulting more phenolic compounds in plant cells that being released into the solvent matrix [16]. Yim et al. [17] also found that the TPC of Schizophyllum commune was increased when the temperature was raised from 30 to $42.5{ }^{\circ} \mathrm{C}$. However, a decreasing of TPC from 42.5 to $55{ }^{\circ} \mathrm{C}$ was observed which probably due to the destruction of phenolic compounds. The increasing temperature enhances the extraction, but at beyond a certain extent, phenolic compounds could be destroyed [17]. Besides, the stability of compounds could be affected due to chemical and enzymatic degradation or losses by thermal decomposition which resulting in a decreasing of TPC [18].

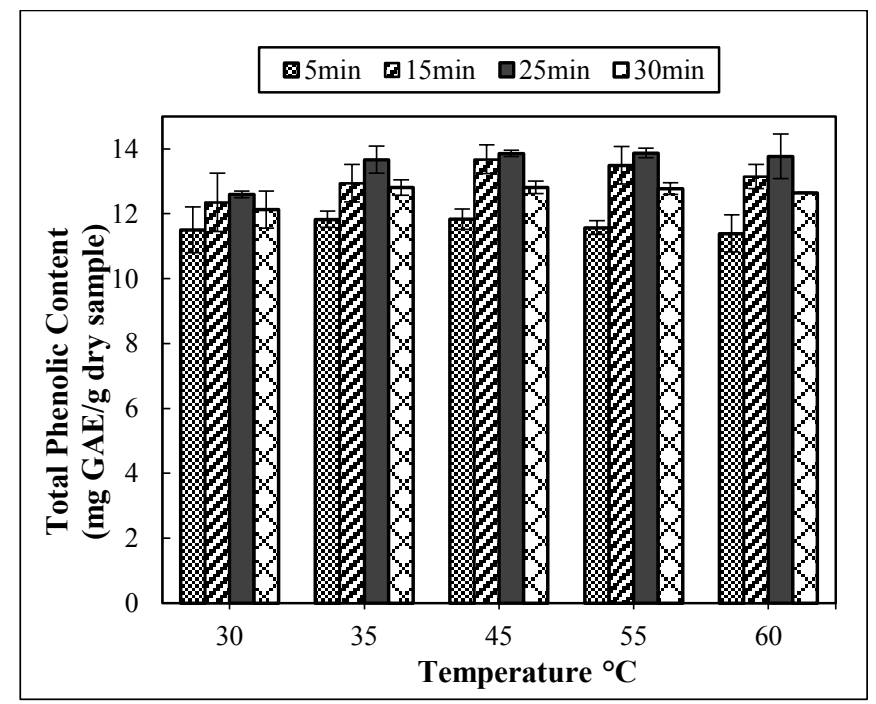

Figure 1. The total phenolic content of C. nutans extracts at different times and temperatures

Statistical evaluation of both extraction conditions (temperature and time) has demonstrated a high significant difference $(p<0.05)$ with time which indicated more significant effect on TPC than temperature with the highest $\mathrm{f}$ value of 55.10. This finding is parallel with those found by Gan and Latif [19], as the extraction of TPC from Parkia speciosa pod was shown as more likely to be significantly affected by the extraction of time than temperature. They suggested that increasing the temperature may enhance the internal reaction between phenols and other plants components which further hindered the extraction. Thus, extraction time becomes significant since 
larger extraction periods might cause more extended polyphenol losses. Moreover, the increase of temperature enhances the contact time for the disintegration of plant cells by cavitation bubbles which also enhance the extraction of phenolics [20]. Nevertheless, prolonged extraction time over 30 min may cause more extended phenolics losses due to the thermal degradation or polymerisation reaction of various phenols which effects the analytical quantification [21].

\section{Analysis of total flavonoid content}

Figure 2 indicates a gradual increase of total flavonoid content (TFC) with increasing of temperature within 30 to 55 ${ }^{\circ} \mathrm{C}$ in ranging of $8.97 \pm 0.68$ to $12.25 \pm 1.01 \mathrm{mg}$ quercetin/g of dry sample and followed by a slight decrease when the temperature was above $55^{\circ} \mathrm{C}$. Increasing temperature in UAE might soften the plant tissue, weaken the cell wall integrity and enhance phenolic compounds solubility thus, resulting in a higher dissolution of phenolics in solvent [22]. However, the increase of ultrasonic temperature in this study gives only a slight increase of TFC. This finding was similar with Gan and Latif [19], who also found that the temperature ranges between 35 until $55^{\circ} \mathrm{C}$ did not significantly affect the phenolic compounds (flavonoids) Parkia speciosa pod. This could be explained through the presence of thermal stability of flavonoid compounds in $C$. nutans leaves within the temperature range and the increase of TFC might be due to the disintegrating of $C$. nutans wall by ultrasonic waves that helps the release of flavonoids in the solvent which then increasing the TFC [23]. Nevertheless, a higher temperature of $60{ }^{\circ} \mathrm{C}$ significantly reduces TFC, possibly by denaturation of cell membranes. This finding was similar with Cacae et al. [24], which found that the degradation of flavonoids may occur when the temperatures exceeds $50{ }^{\circ} \mathrm{C}$. Teh and Birch. [25], also reported that TFC from canola seed cake extracts rose with temperature from 40 to $50{ }^{\circ} \mathrm{C}$, but decreases at $60{ }^{\circ} \mathrm{C}$ due to the decomposition of flavonoid compounds.

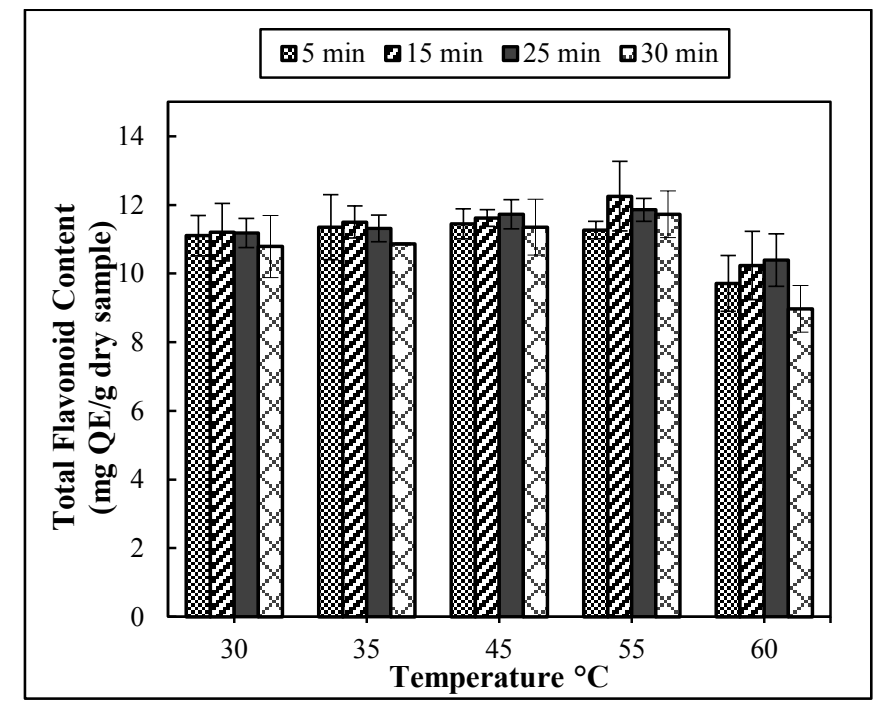

Figure 2. The total flavonoid content of $C$. nutans extracts at different times and temperatures

A significant difference $(p>0.05)$ between the temperature and extraction of flavonoids has been described statistically with little difference observed in the TFC in each time of extraction. This observation might be attributed to the presence of various degrees of polymerisation and interactions that occurred between flavonoid compounds in plant cell and the solvent at different extraction time which led to the final equilibrium constant to be attained [26]. Hence, prolonged extraction time in this study was unnecessary and degradation of flavonoid likely happened [27]. On top of that, Durling et al. [28] have proposed that the extraction time of 15 minutes in the ultrasonic assisted extraction is the best duration in extracting the flavonoid compounds. Therefore, it can be concluded that TFC has scored the highest $\left(12.25 \pm 1.01 \mathrm{mg}\right.$ quercetin/g of dry sample) at $55^{\circ} \mathrm{C}$ and 15 minutes of extraction time. 


\section{Nurul Amila et al: TOTAL PHENOLIC, FLAVONOID CONTENT AND ANTIOXIDANT ACTIVITY OF \\ Clinacanthus nutans LEAVES BY WATER-BASED ULTRASONIC ASSISTED \\ EXTRACTION}

\section{Analysis of antioxidant activity}

The changes of purple color of ethanolic 2,2'-diphenyl-1-picrylhydrazyl (DPPH) into yellowish indicates the reduction of DPPH as free stable radical to $\alpha, \alpha$-diphenyl- $\beta$-picryl hydrazine when reacted with compounds of antioxidant [29]. As displayed in Figure 3, the antioxidant activity increases with temperature from 30 to $55{ }^{\circ} \mathrm{C}$ in ranging of 35.56 to $52.88 \%$ inhibition at a given time and eventually decreases at further temperature. The highest antioxidant activity (52.88\% inhibition) was determined at $55{ }^{\circ} \mathrm{C}$ and 25 minutes. Typically, the increasing extraction temperature has generated higher antioxidant activity which is similar to the finding by Pinelo et al. [30] where they found that the stability antioxidant compounds were affected at temperature above $50{ }^{\circ} \mathrm{C}$ and the disruption of the plant cells may affect the antioxidant capacity. Altemimi et.al [21] has revealed that there was reduction of antioxidant activity at temperature above $50{ }^{\circ} \mathrm{C}$. Thus, the decrease of antioxidant activity as rising temperature beyond $55^{\circ} \mathrm{C}$ region has been observed in this study and might conceivably due to the degradation of some thermally unstable antioxidative compounds.

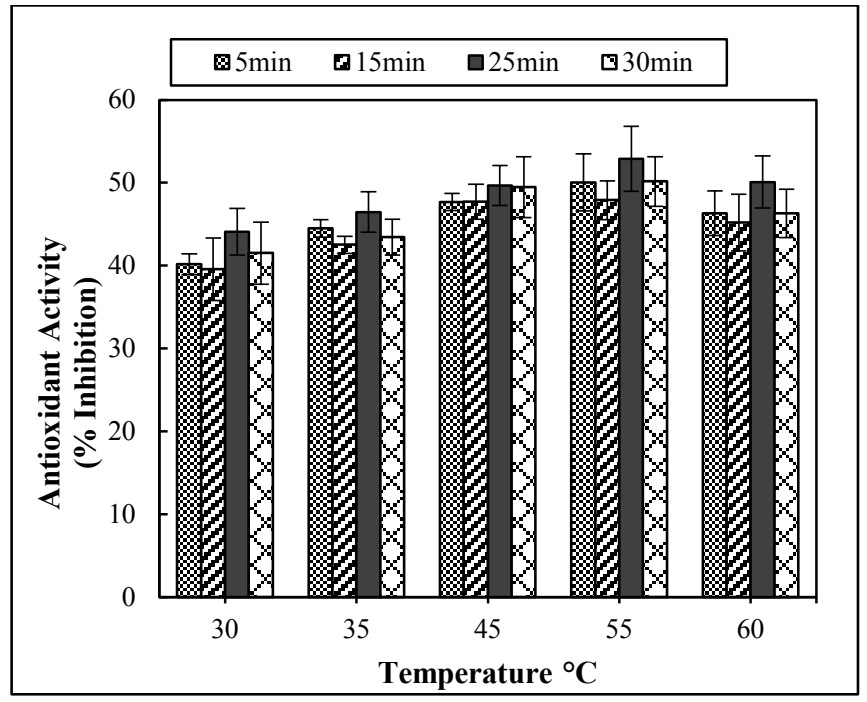

Figure 3. The antioxidant activity of $C$. nutans extracts at different times and temperatures

The result has determined the highest antioxidant activity (52.88\% inhibition) during $55{ }^{\circ} \mathrm{C}$ and 25 minutes of extraction. There is a kind of fluctuation (increase and decrease) of antioxidant activity which was observed between 5 to 30 minutes of extraction. A slight decrease of antioxidant activity can be clearly seen at 15 minutes of extraction which probably explained by the presence of synergistic effect of other involved parameters. Besides, the decomposition of antioxidant compound may happen because of the thermal-based oxidation reaction that occurs during the extraction process [31]. Meanwhile, the statistical analysis has revealed that there was a significant effect of extraction temperature $(p<0.05)$ on antioxidant activity and there was no significant effect of extraction time $(p$ $>0.05$ ) on antioxidant activity. Extended extraction time has also led to an increase of adhesion of diffused particles (antioxidant compound) around the walls of the supporting material like glass or plastic tubes that may interrupt the process of extraction. Hence, this can be used to explain the insignificant effect of time on antioxidant activity in this study [31].

\section{Conclusion}

The present investigation also revealed that the total content of phenolic, flavonoid and antioxidant activity has been successfully extracted from $C$. nutans leaves at elevated temperature and time by water-based ultrasonic assisted extraction (UAE). All the extraction of the total content of phenolic and flavonoid with antioxidant activity were achieved highest at temperature $55^{\circ} \mathrm{C}$ and subsequently degraded with further extraction temperature. Hence, this study showed that $C$. nutans extraction could have been benefited from UAE and promised the potential to be used for the herbs utilization of beneficial food materials, nutraceuticals and pharmaceuticals at manufacturing industry. 


\section{Acknowledgement}

The financial support for this project was provided by Takasago, 4B264 and NRGS, 4H025 from MOE, Malaysia and Malaysia-Japan International Institute of technology (MJIIT), Universiti Teknologi Malaysia which is gratefully acknowledged.

\section{References}

1. Kumar Dash, G. and Deb, J. (2014). Pharmacognostical studies on stem bark of Acacia ferruginea DC. Der Pharmacia Lettre, 6(3): 61-66.

2. Aslam, M. S., Ahmad, M. S., Mamat, A. S., Ahmad, M. Z. and Salam, F. (2016). Antioxidant and wound healing activity of polyherbal fractions of Clinacanthus nutanss and Elephantopus scaber. Evidence-based Complementary and Alternative Medicine, 2016: 1-14.

3. Alam, A., Ferdosh, S., Ghafoor, K., Hakim, A., Juraimi, A. S., Khatib, A. and Sarker, Z. I. (2016). Clinacanthus nutans: A review of the medicinal uses, pharmacology and phytochemistry. Asian Pacific Journal of Tropical Medicine, 9(4): 402-409.

4. Yahaya, R., Dash, K., Abdullah, M. S. and Mathews, A. (2015). Clinacanthus nutans (burm. F.) Lindau: A useful medicinal plant of south-east Asia. International Journal of Pharmacy and Pharmaceutical Research, 7(6): 1244-1250.

5. Tee, L. H., Ramanan, R. N., Tey, B. T., Chan, E. S., Azrina, A., Amin, I., Bao, Y., Lau, C. Y. and Prasad, K. N. (2105). Phytochemicals and antioxidant capacities from Dacryodes rostrata fruits. Medicinal Chemistry, 5(1): 23-27.

6. Solibun, A. and Sivakumar, K. (2016). Sabah snake grass extract pre-processing: Preliminary studies in drying and fermentation. IOP Conf. Series: Earth and Environmental Science, 36: 1-7.

7. Gharekhani, M., Ghorbani, M. and Rasoulnejad, N. (2012). Microwave-assisted extraction of phenolic and flavonoid compounds from Eucalyptus camaldulensis Dehn leaves as compared with ultrasound-assisted extraction. Latin American Application Research, 42: 305-310.

8. Raya, K. B., Ahmad, S. H., Farhana, S. F., Mohammad, M., Tajidin, N. E. and Parvez, A. (2015). Changes in phytochemical contents in different parts of Clinacanthus nutans (Burm. f.) Lindau due to storage duration. Bragantia, 74: 445-452.

9. Susanti, R. F., Kurnia, K., Vania, A. and Reynaldo, I. J. (2015). Total phenol, flavonoid and antioxidant activity of Physalis angulata leaves extract by subcritical water extraction. Modern Application Science, 9(7): 190-198.

10. Pang, S. F., Yusoff, M. M., Abdullah. C. L. and Gimbun, J. (2015). Ultrasonic assisted extraction of phenolic and flavonoid content from Orthosiphon stamineus leaves. Science Technology Progress, 1: 10-13.

11. Picó, Y. (2013). Ultrasound-assisted extraction for food and environmental samples. TrAC Trends in Analytical Chemistry, 43: 84-99.

12. Dent, M., Dragović-Uzelac, V., Elez Garofulić, I., Bosiljkov, T., Ježek, D. and Brnčić, M. (2015). Comparison of conventional and ultrasound-assisted extraction techniques on mass fraction of phenolic compounds from sage (Salvia officinalis L.). Chemical and Biochemistry, 29: 475-484.

13. Vilkhu, K., Mawson, R., Simons, L. and Bates, D. (2008). Applications and opportunities for ultrasound assisted extraction in the food industry: A Review. Innovative Food Science and Emerging Technologies, 9(2): 161-169.

14. Tan, S. P., Parks, S. E., Stathopoulos, C. E. and Roach, P. D. (2014). Extraction of flavonoids from bitter melon. Food and Nutrition Sciences, 5(5): 458-465.

15. Sharifi, A., Mortazavi, S. A., Maskooki, A., Niakousari, M. and Elhamirad, A. H. (2013). Optimization of subcritical water extraction of bioactive compounds from barberry fruit (Berberis vulgaris) by using response surface methodology. International Journal of Agriculture and Crop Sciences, 6(2): 89-96.

16. Altemimi, A., Watson, D. G., Choudhary, R., Dasari, M. R. and Lightfoot, D. A. (2016). Ultrasound assisted extraction of phenolic compounds from peaches and pumpkins. PLoS ONE, 11(2): 1-20.

17. Yim, H. S., Chye, F. Y., Rao, V., Low, J. Y., Matanjun, P., How, S. E. and Ho, C. W. (2013). Optimization of extraction time and temperature on antioxidant activity of Schizophyllum commune aqueous extract using response surface methodology. Journal of Food Science and Technology, 50(2): 275-283. 
Nurul Amila et al: TOTAL PHENOLIC, FLAVONOID CONTENT AND ANTIOXIDANT ACTIVITY OF

Clinacanthus nutans LEAVES BY WATER-BASED ULTRASONIC ASSISTED

EXTRACTION

18. Kiassos E., Mylonaki S., Makris D. P., Kiassos P. K. E, Mylonaki S., Makris D. P. and Kefalas P. (2009). Implementation of response surface methodology to optimise extraction of onion (Allium cepa) solid waste phenolics. Innovative Food Science Emerging Technology, 10: 246-252.

19. Gan, C. Y. and Latiff, A. A. (2011). Optimisation of the solvent extraction of bioactive compounds from Parkia speciosa pod using response surface methodology. Food Chemistry, 124: 1277-1283.

20. Wang, J., Sun, B., Cao, Y., Tian, Y. and Li, X. (2008). Optimisation of ultrasound-assisted extraction of phenolic compounds from wheat bran. Food Chemistry, 106: 804-810.

21. Gimbun, J., Ishak, N. F., Muhammad, N. I. S., Pang, S. F., Kadir, M. A. A., Ramli, H. and Khadisah, Z. (2014). Ultrasonic assisted extraction polyphenols and antioxidant from Nigella sativa seed. Journal of Engineering and Technology, 5(2): 17-26.

22. Tabaraki, R. and Nateghi, A. (2015). Optimization of ultrasonic-assisted extraction of natural antioxidants from rice bran using response surface methodology. Ultrasonics Sonochemistry, 18(6): 1279-1286.

23. Altemimi, A., Choudhary, R., Watson, D. G. and Lightfoot, D. A. (2015). Effects of ultrasonic treatments on the polyphenol and antioxidant content of spinach extracts. Ultrasonic Sonochemistry, 24: 247-255.

24. Cacace J. E. and Mazza G. (2003) Mass transfer process during extraction of phenolic compounds from milled berries. Journal of Food Engineering, 59: 379-389.

25. Teh, S. S. and Birch, E. J. (2014). Effect of ultrasonic treatment on the polyphenol content and antioxidant capacity of extract from defatted hemp, flax and canola seed cakes. Ultrasonics Sonochemistry, 21(1): 346-353.

26. Silva, A. J., Silva, J. R., de Souza, N. C. and Souto, P. C. (2014). Membranes from latex with propolis for biomedical applications. Materials Letters, 116: 235-238.

27. Wang, T., He, F. and Chen, G. (2014). Improving bio accessibility and bioavailability of phenolic compounds in cereal grains through processing technologies: A concise review. Journal of Functional Foods, 7: 101-111.

28. Durling, N. E., Catchpole, O. J., Grey, J. B., Webby, R. F., Mitchell, K. A., Foo, L. Y. and Perry, N. B. (2007). Extraction of phenolics and essential oil from dried sage (Salvia officinalis) using ethanol water mixtures. Food Chemistry, 101(4): 1417-1424.

29. Sharma, O. P. and Bhat, T. K. (2009). DPPH antioxidant assay revisited. Food Chemistry, 113(4): 1202-1205.

30. Pinelo, M., Rubilar, M., Jerez, M., Sineiro, J. and Núñez, M. J. (2005). Effect of solvent, temperature, and solvent-to-solid ratio on the total phenolic content and antiradical activity of extracts from different components of grape pomace. Journal of Agricultural and Food Chemistry, 53(6): 2111-2117.

31. Sathishkumar, T., Baskar, R., Aravind, M., Tilak, S., Deepthi, S. and Bharathikumar, V. M. (2013). Simultaneous extraction optimization and analysis of flavonoids from the flowers of Tabernaemontana heyneana by high performance liquid chromatography coupled to diode array detector and electron spray ionization/mass spectrometry. International Scholarly Research Notices Biotechnology, 13: 1-10. 